\title{
ORGANIZAÇÃO JUDICIÁRIA NAS ORDENAÇÕES MANUELINAS
}

\author{
JUDICIAL ORGANIZATION IN MANUELINE ORDINANCES
}

Rosimeire Ventura Leite"

\begin{abstract}
Resumo:
O presente trabalho é um estudo sobre a organização judiciária portuguesa nas Ordenações Manuelinas (1514-1521), trazendo também questões de natureza processual civil e penal. O objetivo é mostrar a estrutura de distribuição da justiça que foi sendo construida a partir da formação do Estado português, buscando, assim, compreender melhor o exercício da jurisdição e as características do processo.
\end{abstract}

Palavras-chave: Direito lusitano. Ordenações Manuelinas. Organização Judiciária. Processo.

Abstract:

The present work is a study on the Portuguese judiciary organization in the Manuelinas Ordinances (1514-1521), also bringing questions of civil and criminal procedural nature. The objective is to show the structure of distribution of the justice that was being constructed from the formation of the Portuguese State, searching, thus, to better understand the exercise of the jurisdiction and the characteristics of the process.

Keywords: Portuguese Right. Manuelinas ordinances. Judiciary organization. Process.

1. Introdução

O objetivo do presente trabalho é analisar a organização judiciária portuguesa nas Ordenações Manuelinas (1514-152I), destacando alguns aspectos processuais.

Estudar a organização judiciária implica acompanhar o próprio desenvolvimento do Estado português, uma vez que a distribuição da justiça se erige como uma atividade fundamental para a convivência e crescimento de um grupo humano.

Para esta análise, partimos de algumas considerações sobre a evolução histórica da organização judiciária portuguesa, optando pelo período correspondente ao final do século XIJ até o século XVI. Em seguida, abordamos as Ordenações

Doutoranda em Direito Processual Penal pela Faculdade de Direito da Universidade de São Paulo, Juiza de

Direito Tribunal de Justiça da Paraiba e professora universitária da Universidade Estadual da Paraiba. 
Manuelinas, destacando o contexto histórico e social em que veio a lume. bem como sua contribuição.

Por fim, enfatizamos a organização judiciária na referida compilação. enumerando e comentando os cargos que entendemos mais importantes no âmbito dos três tribunais de maior relevo à época. ou seja, a Casa de Suplicação, o Desembargo do Paço e a Casa do Cível.

O estudo, portanto, é um convite para que compreendamos melhor a estrutura judiciária portuguesa, a qual teve considerável influência sobre a formação da organização brasileira. Além disso, é uma interessante perspectiva da formação de um Estado, de um povo e da forma como decidiu organizar sua justiça.

2. Considerações sobre a organização judiciária portuguesa

A organização judiciária portuguesa leve sua evolução marcada pela própria estruturação da figura do Estado. A justiça, como uma das funções estatais, encontrou, inicialmente, as mesmas dificuldades inerentes à afirmação do poder e de uma ordem social e política.

Muito embora o nosso objetivo se restrinja a analisar esta organização ao tempo das Ordenações Manuelinas, entendemos imprescindível mencionar alguns aspectos sobre a evolução das instituições jurisdicionais, partindo do período da formação do Estado português, a partir do século XII.

Diz-se, neste contexto, que "nos começos da monarquia portuguesa a organização judiciária é assaz complexa, incerta e irregular" de modo que "poder judicial e administração civil e militar é de regra que se confundam" '

De fato, nos primeiros tempos, o Rei concentrava em suas mãos todas as decisõcs, sendo auxiliado por pessoas investidas em cargos importantes, amigos e conselheiros. A função régia, já após o reconhecimento do Reino de Portugal pela Santa Sé (1179), abrangia "a chefia militar, a realização da justiça, a proteção da Igreja e o desenvolvimento do território" O Rei, portanto, era o maior juiz, podendo conhecer de todas as causas que the fossem apresentadas. ${ }^{2}$

Estas pessoas que aconselhavam o Rei, juntamente com a família real, era o que constituia a cirria régia ou corte, conforme menciona Caetano.

JUDICIÁRIO. In: GRANDE Enciclopédia Portuguesa e Brasileira. Lisboa: Rio de Janeiro: Fditorial Enciclopédia, 1935-60. v. XIV. p. 35I.

2 CAETANO, Marcello. História do dirvito pormuguês - sécs. XII - XVI. Lisboa: Verbo, 2000. p. 206-207. Acrescenta ainda o autor que a separação completa entre as atividades administrativas e jurisdicionais só ocorreria em Purtugal a partir do sic. XIX (ob. cit, p. 215).

Id. Ibid.. p. 212. 
Seguindo a periodização apresentada pelo referido autor, com a ressalva da necessidade de evitar generalizações, conforme ele mesmo observa, tem-se que no final do séc. XII até a primeira metade do séc. XIII, período de formação do Estado, em regra, as funções estatais estavam concentradas nas mãos de uma mesma pessoa.

Já na fase de consolidação do Estado português (1248-1495), em que a autoridade do rei se firmava cada vez mais, o aumento das atribuições começou a dar ensejo ao surgimento de algumas especializações. Isso se verificou, sobretudo, no âmbito da justiça, com os cargos de sobrejuizes e ouvidores. e com a formação de dois tribunais - a Casa do Cível, com sede fixa em Santarém e depois em Lisboa, e a Cusa de Justiça da Corte, que andava com o Rei.

Estes dois tribunais se mantiveram nas Ordenações Afonsinas (1446). A Casa de Justiça da Corte com duas mesas. e que no reinado de D. Afonso $\mathrm{V}$ passou a se chamar Casa de Suplicação; e a Casa do Cível, também denominada Casa do Cível e do Crime. e que já estava fixa em Lisboa. Naquele periodo, já se destacavam também da Casa de Suplicação os desembargadores do Paço. ${ }^{4}$

No mesmo sentido da contextualização histórica acima procedida. acrescenta Hespanha que "os diversos órgãos da administração central vão sendo originados por um processo de progressiva diferenciação do tribunal real (ou cúria regia) dos primeiros tempos da monarquia" No tribunal da corte, especificamente. logo foram se delineado algumas divisões como a separação entre matérias civeis e criminais. a distinção entre petições de graça e de justiça, e entre recurso de agravo e apelação. ${ }^{5}$

Assim. matérias que antes eram apreciadas pelo Rei começaram aos poucos a se destacar dele, criando núcleos autônomos, que se transformariam nos tribunais especializados. ${ }^{6}$

Sobre a dificuldade de conhecer precisamente o desenvolvimento da organização judiciária portuguesa, comenta Gama Barros que esta tarefa é bastante árdua quando se refere ao período até meados do século XIII. Na seqüência. as informações são mais claras na fase que se segue até o séc. XIV. Por fim, foi com as Ordenações Afonsinas que começou a "difundir-se uma luz mais brilhante sobre esta parte da história social" "

CAETANO, Marcello. História do direito português - sécs. XII - XVI, cit., p. 215; 304-305, 310; 482-484.

HESPANHA, Manuel António. História das Instituiçōes: época medieval e moderna. Coimbra: Almedina, 1982. p. 335-337.

ld. Ibid., p. 338.

BARROS, Henrique da Gama. História da administração pública em Portugal nos seculos X7I e XV. 2. ed. Lisboa: Livraria Sá da Costa, 1946. t. 2. p. 261-262. 
Em seguida, com as Ordenações Manuelinas (15/4-1521), esta estrutura já estava bastante delineada, sendo a competência dos diversos órgãos mais específica e melhor delimitada.

\section{Ordenações Manuelinas}

As Ordenações do Reino de Portugal representaram um importante esforço de sistematização do direito. fruto das necessidades impostas pelo aumento das normas que regiam a vida em sociedade e também pelo desenvolvimento econômico e politico.

Neste sentido, destaca Velasco que "a multiplicidade de normas jurídicas (representada pelos foros e cartas de foral, pelas disposições do direito justinianeu e canônico, pelos capítulos de Cortes, leis régias, etc.), e as contradições originadas dessa multiplicidade (dificultando sobremaneira a administração da Justiça), foram a causa imediata das Ordenações portuguesas" ${ }^{*}$

Assim, as Ordenações Afonsinas foram concluídas em 1446, tendo a empresa iniciado ainda no reinado de D. João I, sob a responsabilidade de João Mendes, vindo, porém, a consumar-se no mesmo ano em que $\mathrm{D}$. A fonso $\mathrm{V}$ atingiu a maioridade e assumiu o trono." Sua vigência foi em um periodo em que ainda havia grandes dificuldades de reprodução de cópias, o que retardou a divulgação.

Note-se que antes das Afonsinas, houve outras tentativas de compilação, como o Livro das Leis e Posturas, o Livro das Leis Antigas e as Ordenações de D. Duarte. ${ }^{10}$

Passado o tempo, novamente fez-se necessário um trabalho de sistematização e aperfeiçoamento das normas do reino, o que foi levado a efeito no reinado de D. Manuel, o qual governou em uma época de muitas mudanças. como os descobrimentos maritimos e a introdução da imprensa.

Sobre este contexto histórico do séc. XVI, comenta Azevedo que:

[...] reabilita-se o pensamento pelo retorno à antiguidade clássica, conhece-se enorme impulso nas letras e nas artes. reaviva-se o humanismo, opera-sc a renovação da escolástica, primeiro com Vitória, a seguir com Suares e De Soto. Desenvolve-se o comércio, difundindo-se o saber pela imprensa, deslumbra-se o velho mundo com o

8 VELASCO, Ignácio M. Poveda. Ordenações do reino de Portugal. Revista da Faculdade de Direito da Universidade de São Paulo, São Paulo. v. 89, p. 11-67, jan./dez. 1994. p. 17.

9 AZEVEDO, Luiz Carlos de. Introdução à história do direiro. São Paulo: Revista dos Tribunais. 2005. p. 190.

to SILVA, Agathe E. Schmidt da. As ordenações Filipinas e o direito brasileiro. Revista Estudos Juridicos. São Leopoldo, Universidade do Vale do Rio dos Sinos, v. 28, n. 73, p. 59-84, maio/ago. 1995. p. 70. 
encantamento proporcionado por um mundo novo que a todos seduz e empolga."

Natural, portanto, que todas estas mudanças exigissem uma legislação que acompanhasse os avanços dos novos tempos e as possibilidades que se vislumbravam naquela fase do desenvolvimento de Portugal.

A primeira edição das Ordenações Manuelinas ocorreu em 1514, sendo que $D$. Manuel determinou a destruição, permitindo a publicação da versão definitiva apenas em 1521.

As Ordenações mantiveram basicamente a mesma estrutura das Afonsinas, dividindo-se $\mathrm{cm}$ cinco livros, estando no primeiro as regras sobre os cargos administrativos e ligados à justiça e no terceiro as normas sobre o processo civil. Suprimiu-se, porém. a parte referente aos mouros e judeus, que já haviam sido expulsos do território português em 1496, conforme menciona Gomes da Silva. ${ }^{12}$

Um dos aspectos inovadores foi quanto ao estilo. uma vez que "em geral, todas as leis são reescritas, em estilo decretório. como se de leis novas se tratasse, umbora não passando muitas vezes de nova forma dada a leis já vigentes" "i

Ainda se manteve a influência do Direito Romano-Canônico, hem como a preocupação com os casos de lacuna da lei, devendo-se recorrer ao Rei quando tivessem sido esgotados todos os outros meios de suprimento.

No processo civil, dois aspectos merecem especial atenção, quais sejam, a introdução da ação decendiária ou ação de assinação em dez dias (L 3, tít. XVI), que agilizava o recebimento de coisas ou valores pelo credor, e as regras de contagem dos prazos processuais, que já se mostravam bastante claras e objetivas (L 3, tit. XII).

No processo penal, comenta Almeida Júnior que naquela época os feitos criminais "não se iniciavam por clamores e sim por querelas juradas, por denúncias, ou por inquirições devassas" "."

Pode-se dizer, desta forma, que as Ordenações Manuelinas representaram um aperfeiçoamento da sistematização do Direito lusitano. Contudo, ainda persistiram falhas quanto à organização, ao formalismo do processo e ao estilo rebuscado e repetitivo, o que, porém, não retira o seu mérito naquele momento histórico.

\footnotetext{
AZEVEDO, Luiz ('arlos de. op. cil., p. 206.

12 SILVA, Nuno J. Gomes da. Spinosa. História do direito porluguês: fontes de direito. 3. ed. Lisboa: Calouste Gulbenkian, 2000. p. 296.

13 VElasCo, Ignácio M. Poveda. Ordenaçōes do reino de Portugal. Ruvista da Faculdade de Direito da Universidade de São Paulo, São Paulo, v. 89, p. 11-67, jan.idez. 1994. p. 22.

is ALMEIDA JÚNIOR. João Mendes de. O processo criminal brusileiro. 4. ed. Rio de Janeiro: Freitas Bastos, 1959. v. 1. p. 123.
} 


\section{Organização judiciária nas Ordenações Manuelinas}

Vistos, pois, alguns aspectos das Ordenações Manuelinas, analisemos a organização judiciária naquele periodo, destacando os tribunais superiores e os principais cargos de cada um deles.

Importa notar, desde logo, que no período destas Ordenações as atribuições dos três tribunais - Casa de Suplicação, Desembargo do Paço e Casa do Cível - já estavam bastante definidas. Além do que, as principais inovações em relação às Afonsinas teriam mesmo ocorrido no livro I, conforme destaca Rocha, ao falar sobre a organização das cortes superiores. ${ }^{15}$

\subsection{Da Casa de Suplicação}

A Casa de Suplicação era o maior tribunal da justiça em Portugal, tendo perdurado sua vigência até 1834, correspondendo ao Supremo Tribunal de Justiça na organização judiciária moderna. Para este tribunal iam as principais causas cíveis e criminais. $^{16}$

Pelas informações doutrinárias, no séc. XIV, uma reforma promovida no tribunal da corte efetivou a separação das funções entre os juizes da suplicação e da apelação civil. ${ }^{17}$

Com a separação já plenamente consumada ao tempo das Ordenações Manuelinas, na edição de 1521, a Casa de Suplicação se constituía em um "órgão de caráter jurisdicional com competência para conhecer dos recursos ordinários que não fossem da competência da Casa do Cível" 18

\subsubsection{Do Regedor da Casa de Suplicação}

O regedor da Casa de Suplicação, ou regedor da Justiça. era uma espécie de presidente daquele Tribunal, devendo ser de origem portuguesa e dotado de certas qualidades. como ser fidalgo e ter autoridade. assumindo ainda o compromisso de bem cumprir as Ordenações, mediante juramento prestado perante o Chanceler-mor.

is ROCHA, M. A. Coelho da. Ensuio sobre a história do governo e legislação do Portugal. 7. ed. Cuimbra: Imprensa da Universidade, 1896. p. 128.

16 SUPLICAÇÃO. In: GR.ANDE Enciclopédia Portuguesa e Brasileira. Lisboa; Rio de Janeiro: Editorial Enciclopédia, 1935-60. v. XXX. p. 380.

17 TRIBUNAL. In: GRANDE Fnciclopédia Portuguesa e Brasileira. Lisboa; Rio de Janeiro: Editorial Enciclopédia, 1935-60. v. XXXII. p. 778.

18 HESPANHA, Manuel António. História das Instituições: época medieval e moderna. ('oimbra: Almedina, 1982. p. 434. 
Corregedores das comarcas, juizes de fora e uuvidores também faziam juramento para ingressar no cargo. Dentre suas funções, havia a de exercer uma espécie de fiscalização sobre a conduta dos desembargadores e oficiais. Assim, em caso de algum erro, o regedor poderia adverti-los em separado, pcla primeira vez, e depois. persistindo no defeito, fazê-lo perante outros oficiais, a fim de que se emendassem pela vergonha. Por fim, caso insistissem na má conduta, era dever do regedor informar ao rei para que adotasse o melhor castigo.

O regedor também escolhia um sacerdote que rezasse missa todos os dias pela manhã na Relação e, após a missa, fazia ele a distribuição dos desembargadores nas mesas respectivas, a fim de começar os desembargos.

Nos casos criminais em que fosse cabível a "morte natural" ou seja, a execução, deveriam atuar quatro desembargadores juntamente com o juiz do feito, sendo a decisão obtida com o acordo de três deles. Quando não fosse o caso de morte, atuariam apenas dois desembargadores e o juiz do feito.

Inturessa também observar, já naquela época, a preocupação com o aproveitamento do tempo, ordenando-se que os desembargadores, depois que começassem a despachar, deveriam permanecer sentados, só se ausentando por necessidade e retornando logo em seguida. Neste sentido, determinava-se ainda que o tempo não fosse desperdiçado em "falas c práticas não necessárias, nem em outras semelhantes ocupações, em que se gaste o tempo como não deve" (L l, tít. I, 11).

Os desembargadores deveriam assim atuar por quatro horas suguidas. passadas "por relógio de areia", sendo também proibido o ingresso de outras pessoas na Relação durante aquele período, para que não houvesse prejuízos aos trabalhos. Tudo isso era controlado pelo regedor daquela Corte.

Após as horas de desembargo, havia as audiências, distribuídas pelos dias da semana, sendo que o regedor poderia fazer as alterações nccessárias (L I, tít. I, 18). Importante ainda que o regedor se informasse mensalmente sobre o bom andamento das audiências, cumprindo-lhe advertir não-só os escrivães, como também os desembargadores que não observassem as regras (L 1, tít. I, 21).

Quanto aos feitos civcis, deveriam ser relatados perante as partes ou seus procuradores, lendo-se aquilo que fosse necessário e acordado. Depois, as partes ou seus procuradores saíam para que houvesse o julgamento. A sentença era escrita pelo juiz do feito e assinada por todos que dela tomassem parte.

Em caso de suspeição contra algum dos desembargadores, caberia à parte informá-la ao regedor, o qual analisava a questão com os desembargadores, designando o 
feito a outro, na hipótese de acolhimento ( $\mathrm{L}$ 1, tít.l, 25). Também em situações de impedimento, era atribuição do regedor providenciar o substituto (L 1, tít. I, 30).

$\mathrm{O}$ regedor ainda cra encarregado da parte financeira. mandando fazer os pagamentos dos desembargadores, escrivães e outros funcionários (L I, tít. I, 23).

Vê-se, deste modo, que o regedor de Justiça tinha amplas atribuições, de caráter jurisdicional, administrativo, financeiro e disciplinar. A ele cabia zelar pelo bom andamento dos trabalhos, fiscalizando a conduta dos funcionários e aplicando-lhes punições. ${ }^{19}$

Importante notar, por fim, o controle que deveria haver ao fim de cada ano sobre os feitos despachados a a despachar, no que - talvez - possamos denominar de uma forma de controle de produtividade ( L I, tít. I, 45). Controle que também se fazia sobre os réus presos, mensalmente, e sobre os feitos a eles referentes, verificando-se se em relação a eles havia algum retardo (L 1, tít. 1, 46).

\subsubsection{Do Chanceler-Mor}

O segundo cargo na Casa de Suplicação era o de chanceler-mor, sendo o seu juramento tomado pelo regedor na presença de todos os desembargadores. Tinha ele grande poder de fiscalização sobre os documentos, cabendo-lhe detectar erros ou contradições em relação ao texto das Ordenações, fossem tais documentos assinados pelos desembargadores ou pelo próprio rei (L 1, tít. II. 3).

Era este funcionário que detinha sob sua guarda o selo real. Encarregavase, pois, de colocar o seu visto sobre cartas e sentenças. quando estivessem corretas. Poderia também apreciar questões referentes a suspeição, ressalvada a atribuição do regedor, conforme seu regimento (L 1, tít. II, 7).

Neste sentido, observa-se que "todas as cartas e quaisquer outros diplomas, de graça ou de justiça, assinados pelo Rei ou pelos desembargadores, deviam ser examinados pelo chanceler-mor, para lhes pôr o selo depois de ter verificado a sua legalidade e que não iam contra os direitos da coroa, nem das classes ou de alguma pessoa em particular" 20

19 Assim, por exemplo, em relação aos Corregedores das Comarcas (L 1, tít. I, 40), aos Meirinhos da Corte (L I, tit. I, 4I), aos Escrivães (L I, tít. I, 42) e Carcereiros (L I, tit. I, 43).

20 BARROS, Henrique da Gama. História da administração pública em Portugal nos séculos XIl e XI' 2. ed. 1.isboa: Livraria Sá da Costa, 1946. t. 3. p. 230-231. 
Sobre este cargo, comenta Câmara que o chanceler-mor era "uma espécie de ministro sem pasta, cujas funções se assemelhavam às dos modernos secretários de Estado de Interior e Justiça" 21

A ele também cabia publicar as leis e Ordenações, providenciando para que fossem encaminhadas cópias aos corregedores das comarcas. Neste ponto, as Ordenações tratam de questão bastante relevante, que é a publicação das leis e o prazo dentro do qual deveriam entrar em vigor. ${ }^{22}$ Por fim, das decisões do chanceler-mor cabia agravo de petição (L 1, tit. II, 34).

\subsubsection{Dos Desembargadores do Agravo}

Estes desembargadores conheciam dos feitos que a eles chegassem através de agravos, a exemplo dos que eram interpostos de sentenças proferidas pelos sobrejuizes, ouvidores e corregedores da corte, disciplinando as Ordenações a forma como deveriam proceder nestes casos (L 1, tít. IV).

\subsubsection{Do Corregedor da Corte dos feitos criminais}

Segundo Gama Barros, o cargo de corregedor da corte deve datar aproximadamente do reinado de Afonso IV, sendo que só ganhou maior relevo no governo de D. João I. Com o passar do tempo, porém, houve uma separação de funções, surgindo os cargos de corregedor do crime e corregedor do civel, o que estava claramente definido em 1488."3

Já Hespanha destaca que a este grupo de magistrados cabia "exercer as funções dos corregedores no lugar onde a Corte se encontrava" ${ }^{24}$

Aos corregedores do crime competia o conhecimento dos delitos cometidos, onde a Corte estivesse ou no limite de cinco léguas, disciplinando também as Ordenações quando a acusação poderia ser feita perante tais corregedores ou perante o juiz do lugar onde ocorreu o fato ( $\mathrm{L} 1$, tít. V, 1).

Igualmente. poderia ser requerida aos corregedores dos feitos criminais a carta de seguro.

21 CÂMARA. José. Subsidios para a história do direito pátrio. Rio de Janeiro: Serviçu Gráfico do Instituto Brasileiro de Geografia e Estatistica, 1954. 1. 1. p. 77.

2 Este prazo era de très meses contados da publicação. em todo o Reino, sendo que na Corte, o prazo era de apenas oito dias (L I, tit. II, 9).

23 BARRUS. Henrique da Gama. História da administraçāo pühlica ı’m Porlugal nos séculos XIl e XV. 2. ed. Lisboa: Livraria Sá da Costa. 1946. p. 245-247. 1. III.

I HESPANHA, Manuel António. História das instituiçōes: épocas medieval e modema. Coimbra: Almedina, 1982. p. 341 . 
O corregedor, com parecer do regedor, poderia mandar determinados feitos para a Corte, quando entendesse necessário (I. 1, tít. V. 5). A ele competia ainda desembargar as cartas testemunhais sobre feitos criminais e agravos (L 1, tít. V, 12).

\subsubsection{Do Corregedor da Corte dos feitos cíveis}

Determinam as Ordenações que estes corregedores usassem o regimento aplicado aos corregedores das comarcas, no que não contradissesse o regimento a eles especialmente designado (L 1, tít. VI, início). A eles cabia conhecer, por ação nova, os feitos cíveis, cabendo agravo das suas decisões (L I, tít. VI, l-2).

Tinham também competência relacionada a recursos, para conhecimento de agravos (L 1, tít. Vl, 10).

\subsubsection{Dos Juizes dos Nossos Feitos}

Estes juízes despachavam com os desembargadores, conforme a distribuição que fosse feita pelo regedor da justiça. Por esta designação tem-se "os juizes que tomavam conhecimento dos feitos ou autos em vários tribunais“" ${ }^{\circ}$

\subsubsection{Dos Desembargadores das Ilhas}

A eles cabia conhecer dos feitos cíveis que viessem por apelação ou agravo das ilhas, dentro das matérias especificadas nas Ordenações, e que thes eram distribuídos pelo escrivão.

Tinham também atribuições relacionadas aos feitos criminais. podendo conhecer de apelações e agravos provenientes das ithas, desde que não fosse o caso de se aplicar morte natural ou perda de membro, situações em que a competência seria dos ouvidores da Casa do Cível (L 1, tít. VIII, 4).

$\Lambda$ competência destes desembargadores, portanto, e ao que parece, estava relacionada a um limite territorial, qual seja. os fatos ocorridos nas ilhas. fossem de natureza cível ou criminal, havendo, porém, algumas ressalvas como a questão de tributos, que deveria ser remetida a funcionários da Fazenda (L 1, tít. VIII, 6).

Dentro do limite territorial acima mencionado, podiam passar cartas de segurança e receber querelas de crimes (L I, tít. VIII, 9 e 11 ).

2s JUIZ. In: GRANDE Enciclopédia Portuguesa e Brasileira. Lisboa; Rio de Janeiro: rditorial Enciclopédia. 1935-60. p. 360, v. XIV. 


\subsubsection{Dos Ouvidores da Casa de Suplicação}

Os ouvidores eram magistrados de segunda instância. A eles cabia o conhecimento de apelações de feitos criminais de todos os lugares do reino, com algumas exceções estabelecidas nas Ordenações, assim como de apelações cíveis, ressalvada a competência da Casa do Cível e dos sobrejuízes ( L I, tít. IX, 1).

\subsubsection{Do Ouvidor das Terras da Rainha}

Cabia a estes ouvidores conhecer os feitos criminais que viessem das terras da Rainha por apelação. Também atuavam em agravos cíveis e criminais referentes às mencionadas terras ( $\mathrm{L}$ I t tít. X, 2). Os ouvidores também percorriam as terras da Rainha e faziam correições (L 1, tít. IX, 2).

Sobre as origens deste cargo, comenta Gama Barros que "a existência de um magistrado superior, com jurisdição privativa nas terras da consorte do rei, parece porém ser antiga, achando-se menção do sobrejuiz da rainha num estatuto, acerca das pessoas privilegiadas para citarem perante o tribunal da corte, que se atribui, posto que dubitativamente, ao reinado de Afonso III" 26

\subsection{Do Desembargo do Paço}

Conforme visto, os desembargadores do Paço integravam inicialmente a Casa de Suplicação, destacando-se depois deste órgão e constituindo um núcleo autônomo de conhecimento de determinados feitos. Foi, todavia, com as Ordenações Manuelinas que o Desembargo do Paço obteve um regimento mais específico.

Neste sentido, observa Rocha que "o tribunal do Desembargo do Paço. separado já da Casa de Suplicação por D. João II. ou por D. Manuel, tem aqui o seu regimento especial, encarregado de despachar com o Rei os negócios de graça" ."

Narra-se ainda que "o tribunal do Desembargo do Paço tirou a sua origem dos desembargadores de petições. depois chamados da casinha, por terem no Paço um gabinete onde despachavam com o Rei. Este tribunal acabou em 1833" 28

\footnotetext{
26 BARROS. Henrique da Gama. História da udministração pública em Porlugal nos séculos XII e XV. 2. ed. Lisboa: Livrarıa Sá da Costa, 1946. p. 248, t. III.

27 ROCHA, M. A. Coelho da. Ensaio sobre a história do governo e legislação de Porlugal. 7. ed. Coimbra: Impr. da Universidade, 1896. p. 128.

28 DESEMBARGADOR. In: GRANDE Enciclnpédia Portuguesa e Brasileira. Lisboa; Rio de Janeiro: Editorial Enciclopédia, 1935-60. p. 687, v. VIII.
} 
Aos desembargadores do Paço cabia a manifestação sobre as petições de graça que dissessem respeito à justiça e as cartas dos perdões (L. 1, tít. III, I). ${ }^{29}$ Sobre a distinção entre petições de justiça e petições de graça, observa Hespanha que estas "visavam um objetivo que não podia ser conseguido com a mera aplicação do direito vigente, ou por implicar uma sua derrogação ou dispensa, ou por cair no âmbito da decisão discricionária do soberano" 30

No entanto, dentre as petições graciosas havia também as "petições de graça em matéria de justiça", às quais as Ordenações Manuelinas se referem neste título, abrangendo, assim, as "petições de graça que visassem a alteração de situações jurídicas (emancipação, perdão, legitimação, insinuação de doações, concessão de interditos possessórios) ou que dissessem respeito à situação dos funcionários" 31

Poderiam ainda ser dirigidas aos desembargadores do Paço petições relativas a firimentos, furtos, incêndios, adultério, perda de virgindade, assim como matérias referentes a fugas de presos, levantamento de degredos, dentre outras ( $\mathrm{L}$ 1, tit. III, 6-13).

Além das cartas de perdão, havia também as cartas de privilégios ou liberdades: de legitimação e confirmação de perfilhamentos e doações; e de confirmação de eleição dos juizes ordinários ( $\mathrm{L}$ I, tít. III, 16-17).

\subsection{Da Casa do Cível}

A Casa do Cível era a corte que permanecia em Lisboa, sendo que inicialmente fixou-se em Santarém, só passando em definitivo para aquela cidade, ao que se sabe, em $1434 .^{32}$

Os integrantes desta Casa eram chamados de sobrejuizes, mas a partir da segunda metade do séc. XV adotou-se também a denominação de desembargadores. ${ }^{33}$

A competência desta corte abrangia o conhecimento de feitos cíveis e também criminais que chegavam por recursos.

29 Os perdões estavam relacionados com atos criminosos e quando concididos poderiam ser cumulados com algumas penas. como o degredo para os territórios portugueses na África.

30 HESPANHA. Manuel António. História das instilliçoós: épocas medieval e moderna. Coimbra: Almedina. 1982. p. 336.

31 Id. Ibid., p. 337.

32 TRIBUNAL. In: GRANDE Enciclopédia Portuguesa e Brasileira. I isboa; Rio de Janeiro: Editorial Fnciclopédia, 1935-60. p. 780, v. XXXII. Gama Barros diz desconhecer o ano exato em que esta mudança definitiva aconteceu, mas confirma yue em 1434 a Casa do Civel efetivamente já se encontrava em Lisboa (BARROS. Henrique da Gama. Hisı́ria da administraçăo puiblica em Porlugal nos séculos XII e XV. 2. ed. Lisboa: Livraria Sà da Costa, 1946. p. 275, t. III).

33 CAETANO, Marcello. História do direiro pormguês - sécs. XII - XV. Lisboa: Verbo, 2000. p. 485. 


\subsubsection{Do Governador da Casa do Cível}

As funções do governador da Casa do Civel eram bem semelhantes às do regedor da Casa de Suplicação, sendo igualmente o cargo maior daquele órgão jurisdicional, exigindo-se que fosse pessoa de virtude e que zelasse pelos interesses da justiça. ${ }^{i t}$

Cabia-lhe inicialmente a função de fiscalizar a atuação dos demais oficiais, podendo aplicar punições, como admoestações (L 1, tít. XXIX, 8).

Os trabalhos se desenvolviam também de modo bastante parecido ao que já foi dito sobre a Casa de Suplicação. De fato, depois de ser rezada a missa, os desembargadores eram divididos pelas mesas em que deveriam atuar, juntamente com os ouvidores. Além das mesas dos feitos criminais, havia uma específica para os feitos de Guiné e Índia (L 1, tít. XXIX, 11-12).

O governador poderia juntar todos os desembargadores em casos de maior gravidade e que ensejassem dúvida, devendo indicar um número maior de desembargadores para julgar os feitos criminais em que tivesse de ser aplicada a morte natural (L I, tít. XXIX, 17-18).

A ele competia ainda "prover e conservar os Estilos, e bons costumes acerca da ordenação dos feitos" bem como evitar que na ("asa do Cível se conhecessem de feitos da competência da Casa de Suplicação, não podendo esta igualmente interferir nos assuntos daquela (L 1. tít. XXIX. 23-24).

Interessante notar que, havendo dúvida sobre a competência de uma ou outra Casa. em determinado feito, a decisão caberia aos desembargadores do Paço, devendo ser observada pelo regedor e pelo governador. Trata-se, deste modo. de regra referente a conflito de jurisdição entre as duas cortes (L I, tít. XXIX. 25).

Assim. ao governador, de um modo geral, cabiam atribuições de coordenar os trabalhos da justiça. de fiscalizar. punir e também administrar questões referentes às despesas da Casa.

\subsubsection{Do Chanceler}

Por este funcionário passavam todas as cartas e documentos da Casa do Cível, cabendo-lhe verificar a regularidade. Encontrando erro, devolveria ao governador e aos desembargadores (L 1, tit. XXX,1-2).

3 Observa Caetano que esta denominaçào de governador da ('asa do Civel surgiu no final do século XV (1485) (CAETANO, Marcello. Histöric do direito português - sécs. XII - XVI. Lisboa: Verbo. 2000. p. 486). 
Cabia-lhe também conhecer das suspeições contra desembargadores daquela Casa, ressalvados os casos em que o julgamento poderia ser proferido pelos demais desembargadores na presença do governador (L 1, tít. XXX, 4-5).

Por fim, vê-se que a atividade do chanceler estava ainda relacionada ao controle da atuação dos oficiais e escrivães no exercício das funções destes.

\subsubsection{Dos Desembargadores do Agravo}

$\mathrm{Na}$ Casa do Cível, estes desembargadores eram dois. Trabalhavam juntamente com os demais desembargadores e o governador, podendo conhecer de agravos, cartas testemunháveis e outras petições provenientes das comarcas.

Apreciavam ainda os agravos vindos dos sobrejuizes, dentro de uma determinada alçada, pois, em causas de maior valor a competência seria da Casa de Suplicação (L 1, tít. XXXI, 1).

\subsubsection{Dos Sobrejuízes}

Destaca Caetano que "no reinado de D. Sancho II já na corte figuram magistrados permanentes, encarregados de relatar os recursos de todo o reino e designados por sobrcjuizes" ${ }^{3}$

Os sobrejuizes, nas Ordenações Manuelinas, eram seis e atuavam em todos os feitos que viessem por apelação de todo o reino, ressalvada a competência da Corte que acompanhava o Rei, ou seja, a Casa de Suplicação. Eles recebiam os feitos por distribuição, faziam audiências e deveriam apreciar os processos "sem delonga" ( L 1, tít. XXXII, início).

Além das apelações, conheciam ainda dos feitos que lhes fossem atribuídos pelo governador, assim como dos processos de "viúvas. órfãos e pessoas miscráveis, quando perante eles quiserem litigar" (L 1, tít. XXXII, I).

Cabia-lhes também fiscalizar o comportamento dos escrivães que com eles atuavam, de modo que não houvesse retardo. Encontrando alguém em erro, deveriam tomar as providências ou encaminhar para o chanceler (L I, tít. XXXII. 4).

\subsubsection{Dos Ouvidores do crime}

Competia a estes ouvidores conhecer de agravos vindos de Lisboa e seu termo. bem como das apelações de feitos criminais dos juizes e corregedores daquela

35 CAETANO, Marcello. Histúria do direito português - sécs. XII - XVI. Lisboa: Verbo. 2000. p. 309. 
cidade e de Extremedura, ressalvados os casos que eram da competência da Casa de Suplicação (L 1, tít. XXXIII, l-2).

Também poderiam receber "as querelas de todos os maleficios que forem feitos em Lishoa e seu termo" e ainda conceder cartas de seguro em todos estes casos, salvo quando se tratasse de alguns crimes, como sodomia, traição e heresia (L 1. tít. XXXIII, 3).

\subsubsection{Dos Promotores de Justiça}

O promotor de Justiça devia ser letrado, cabendo-lhe "requerer todas as coisas que pertencerem à Justiça". assim como as que dissessem respeito à conservação da jurisdição real (L 1, tít. XXXIV, início).

Poderia ainda o promotor conhecer de feitos quando os subrejuizes fossem dados por suspeitos. embora o governador pudesse atribuir esta tarefa igualmente a um desembargador. Por fim. conhecia também dos feitos relacionados a viúvas, órfãos ou pessoas miseráveis (L 1. tit. XXXIV, 2-3).

\subsection{Dos órgãos de fiscalização}

Tão importante quanto elaborar e ordenar as leis era a tarefa de impor o seu cumprimento em todo o território do reino. As dcambulações do Rci eram fundamentais para firmar sua autoridade, atender às necessidades do povo e também exercer a atividade fiscalizatória.

No entanto, o aumento da complexidade da ordem estatal logo exigiu a delegação desta atividade a alguns funcionários. Destacamos, assim, neste ponto, duas figuras que desempenhavam esta função de fiscalização e de controle sobre a distribuição da justiça, não-obstante tivessem também outras atribuições determinadas pelo Rei ou em seus regimentos. Trata-se dos corregedores das comarcas e dos juizes de fora.

\subsubsection{Do Corregedor da Comarca}

Os corregedores exerciam atividade de fiscalização junto aos juizes ordinários e outros funcionários. Destaca-se que o cargo de corregedor cabia

[...]ao funcionário que estava à testa de cada uma das grandes circunscrições administrativas do Portugal antigo (comarcas), sendo ele o principal órgão da administração local e o imediato representante do soberano na respectiva 
comarca, competindo-lhe nessa qualidade zelar a jurisdição régia e superintender sobre os oficiais da sua comarca, investigando sobre a maneira como era ministrada a justiça, fiscalizando os serviços da administração e fazenda, corrigindo os abusos e injustiças, e impedindo as usurpações dos direitos reais. ${ }^{36}$

De fato, tinham eles acesso aos procedimentos realizados no lugar por onde passavam, analisando a regularidade. Por isso, o tabelião deveria mostrar-lhes todas as culpas, querelas e inquirições, sob pena de privação do ofício, caso as sonegasse (L I, tít. XXXIX, 1).

Ao corregedor também cabia fazer as eleições dos juizes ordinários e dos oficiais do conselho, se estivesse no lugar na época determinada para tal diligência. Nesta oportunidade, verificava ainda se os juízes haviam feito as audiências a despachado os feitos sem demora (L 1, tít. XXXIX, 3-4).

Poderiam comparecer perante o corregedor as pessoas que se sentissem agravadas pelos juízes, procuradores, alcaides, tabeliãus ou poderosos, bem como aquelas que tinham demandas não resolvidas, pois o corregedor determinaria que o juiz as despachasse ( $\mathrm{L} \mathrm{I}, \mathrm{tit}$. XXXIX, 5).

Não competia ao corregedor conhecer de ação nova ou avocar para si feitos criminais ou civis, exceto nos casos em que as Ordenações assim determinassem. Interessante notar que, dentre as exceções, estava a possibilidade de o corregedor conhecer de feitos relacionados a pessoas poderosas e que the parecesse que o juiz ordinário pudesse ser influenciado no julgamento. Nesta hipótese, poderia até mesmo levar o processo consigo, quando fosse embora do lugar da correição, até que o tivesse completamente resolvido. Do mesmo modo, conheceria dos processos em que o juiz da terra fosse suspeito, sendo que, neste caso, não levaria o processo, mas o confiaria a "um homem bom da Vila" (L 1, tít. XXXIX, 6).

Também o corregedor estava sujeito a punições, como se, por exemplo, não observasse o procedimento correto para efetuar prisões, situação em que pagaria multa ao que foi preso e seria suspenso do oficio (L I, tit. XXXIX, 10).

Ao que parece, o corregedor também fiscalizava questões relacionadas a tributos, verificando se eram retidos sem razão por poderosos ou outras pessoas. Suas atribuições abrangiam ainda a possibilidade de determinar a realização de benfeitorias públicas, como calçadas e pontes (L 1, tít. XXXIX, 14-15).

36 CORREGEDOR. In: GRANDE Enciclopédia Portuguesa e Brasileira. Lisboa: Rio de Janeiro: Editorial Enciclopédia. 1935-60. p. 741-742.v. VII. 
Verificando lugares que estavam despovoados, deveria saber as razões do despovoamento, e a melhor maneira de fazer a ocupação, comunicando ao Rei para as diligências cabiveis (L 1, tít. XXXIX, 18).

Outro aspecto a ser fiscalizado eram as condições em que os réus se encontravam presos, assegurando-se de que estavam bem guardados e que as pessoas por eles responsáveis procediam de maneira correta, devendo ser homens "bons e de boa fama" (L 1, tít. XXXIX, 22).

Poderia o corregedor dar carta de seguro, com exceção de alguns tipos de crimes, sendo-lhe vedado, porém, dar cartas de amizades e de emancipação para os menores de 25 anos (L 1, tít. XXXIX, 24 e 27).

Deveria o corregedor ir aos lugares de correição pelo menos uma vez ao ano, permanecendo por até trinta dias nos lugares maiores, e por vinte dias nos lugares pequenos, ressalvada a necessidade de permanecer por mais tempo em decorrência de algum caso especial (L 1, tít. XXXIX, 30).

Destacando mais uma vez o controle que era exercido sobre a atuação das pessoas que eram encarregadas de algum oficio, vê-se que o corregedor novo deveria fazer inquirição sobre aquele que o antecedeu ( $L$ 1, tít. XXXIX, 42). A inquirição se dava por perguntas feilas a determinadas pessoas nos lugares por onde a correição havia passado. Indagava-se sobre o desenvolvimento dos trabalhos, se andou por todos os lugares, se recebeu dádivas, se realizou audiências, enfim, sobre o cumprimento de seus deveres ( $\mathrm{L}$ 1, tít. XLI, I-14). O resultado desta diligência era encaminhado ao regedor.

Por fim, o corregedor poderia ser demandado por pessoas que tivessem alguma queixa sobre a atuação dele durante a correição (L I, tít. XXXIX, 44).

O corregedor, portanto, tinha uma grande variedade de atribuições. Tomava conhecimento dos fatos que ocorriam no lugar por onde ia, as condutas dos funcionários da Justiça, o modo como as Ordenações estavam sendo cumpridas, adotando as providências nos casos de irregularidades. Além disso, tinha também competências de natureza administrativa, relacionadas à "governança da terra" zelando pelos interesses da Coroa (L 1, tít. XXXIX, 31).

\subsubsection{Dos Juizes de Fora}

A intervenção de juízes de fora foi uma prática que. segundo Hespanha. teria iniciado ainda no séc. XIII. sendo o cargo ocupado progressivamente por pessoas 
com mais cultura jurídica, até o ponto de serem todos letrados, o que efetivamente ocorreu a partir de 1516.

Sobre esta prevalência dos letrados, diz-se que "bacharéis, licenciados e doutores substituem os cavaleiros e escudeiros nas nomeações [...], os quais, em regra, deviam exercer os cargos durante três anos" 38

Tratava-se de uma categoria especifica de magistrados que era indicada pelo rei para atuar em determinado local, em substituição aos juizes da terra. Narra-se que houve reclamações contra a nomeação destes juízes ao tempo de D. João IV, na Corte de 1352, o que ocorreu principalmente pelos gastos que acarretava. Uma das justificativas, porém, para a atuação dos juizes de fora era o fato de que os juízes da terra por vezes sofriam influências das amizades e parentescos nos lugares onde julgavam. ${ }^{? n}$

Não obstante ustas queixas, havia também aqueles que entendiam necessária tal providência. Neste sentido, diz-se que "o 'juiz de fora parte", assim denominado porque era sempre uma pessoa estranha à cidade ou vila onde desempenhava as suas funções, era nomeado pelo rei, e, conquanto essa nomeação lesasse as prerrogativas municipais, tanto mais que importava a cessação da magistratura dos juizes ordinários, não faltam exemplos de ela ser bem acolhida, e até solicitada, por gente da própria população"

Posteriormente, no ruinado de D. Manuel (1495-1521), o número de juizes de fora aumentaria ainda mais. Nas palavras de Almeida Júnior, "D. Manuel que já tinha número suficiente de profissionais, deu passo avante; multiplicou o número de juizes de fora, de tal modo que, em Portugal, já não era comum a existência de juizes ordinários. ou antes, a jurisdição dos juizes ordinários já estava, quase por toda a parte do reino, a cargo de juizes de fora" $" 11$

\subsection{Da Justiça local}

Conforme já observado, a justiça local, inicialmente, era exercida pelas mesmas autoridades que desempenhavam as demais funções na organização do

37 HESPANHA. Manuel António. Históriu das instituições: épocas medieval e moderna. Coimbra: Almedina, 1982. p. 432.

38 JUIZ. In: GRANDE Enciclopedia Purtuguesa e Brasileira. Lisboa: Rio de Janeiro: Editorial Enciclopédia. 1935-60. p. 362, v. XIV:

39 CAFTANO, Marcello. História do direilo português-sérs. XII XVI. Lisboa: Verbo, 2000, p. 324.

40 PERES, Damiăo. História de Porlugal: edição monumental comemorativa do $8^{\circ}$ centenário da fundação da nacionalidade. Porto: Editora Portucalense. 1929. p. 500. v. II.

$"$ ALMEIDA JĹNIOR. João Mendes de. O processo criminal hrasileiro. 4. ed. Rio de Janeiro: Freitas Bastos. 1959. p. 123, v. 1. 
território. Entretanto, posteriormente determinadas pessoas passaram a ser eleitas para esta tarefa.

Consoante observa Delgado, discorrendo sobre o sistema político e jurídico português, que depois seria transportado para o Brasil, "desde que um grupo de moradores de um local chegasse a certo grau de desenvolvimento, eram organizados em 'concelhos' passavam a constituir 'vila' e tinham o direito de. como 'vizinhos eleger as suas autoridades, os seus "juizes"” 42

Por fim, um aspecto importante de se notar foi a intervenção crescente do monarca na distribuição da justiça nos lugares do reino, o que se deu de um modo bem claro através dos juízes de fora.

Deste modo, destacamos, no âmbito da justiça de primeiro grau, dois tipos de magistraturas fundamentais, quais sejam, os juízes ordinários e os de vintena.

\subsubsection{Dos Juízes Ordinários}

Determinam as Ordenações que os juízes tivessem grande diligência no seu trabalho e que atuassem contra os malfeitores sem retardo. Considerando os inconvenientes das devassas gerais, uma vez que muitas informaçõus eram falsas, ficou estabulecido que seriam tiradas apenas as devassas particulares. em casos de morte, violência sexual contra mulheres, moeda falsa, fuga de presos, dentre outras situaçõus especificadas (L 1, tít. XLIV, I).

Aos juizes também competia proceder às inquirições a partir das notícias que recebiam da ocorrência de delitos. Diziam as Ordenações que o juiz que não realizasse as inquirições nas situações previstas, ou não as terminasse dentro do prazo, seria degredado por dois anos, além de pagar multa (L 1, tít. XLIV, I).

Havia ainda a possibilidade de o juiz arcar com perdas e danos por prejuizos causados na realização de devassas (L 1, tít. XI.IV, 2). Aspecto interessante igualmente era a determinação de que o juiz, tão logo entrasse em excrcício em deturminada localidade e nos dez primeiros dias seguintes, iniciasse inquirições devassas sobre o juiz que o antecedeu. Isso para que os juízes "não tomem atrevimento de usarem seus ofícios como não devem" (L 1, tít. XLIV, 4).

O prazo para concluir a inquirição era de trinta dias, ouvindo-se até trinta testemunhas sobre os seguintes aspectos: se o juiz fazia as audiências e despachava sem retardo; se deixou de praticar algum ato por temor, peita, amor, ódio ou negligência; se rcalmente realizou inquirições e querelas, e se mandou prender os malfeitores, ou se foi

\& DELGADO. Luiz. Quadro histórico do direito brasileiro. Recife: Editora da I iniversidade Federal de Pernambuco. 1974. p. 68. 
omisso ou prestou favor a alguém que devia prender; se recebeu dádivas de fidalgos ou outras pessoas; se, em virtude do cargo, tomava mantimentos ou outras coisas sem pagar ou pagando menos do que valiam; se dormiu com mulheres que demandaram perante ele; se fez inquirições sobre o juiz antecessor, sobre a conduta dos alcaides. dos tabeliães e de todos os outros oficiais; se errou em seu oficio, comprou alguma coisa fiada ou tomou algo emprestado, dentre outros aspectos (L 1, tít. XLIV, 5-26).

Vê-se, deste modo, que havia um controle bastante evidente sobre a conduta dos juízes nas localidades em que atuavam, sobretudo quanto ao exercício funcional. Ao que parece, para este controle, contava-se também com a participação dos jurisdicionados, uma vez que eles podiam servir de testemunhas, escolhendo-se as "pessoas de boa fama, de que se presuma que ajam de dizer a verdade, e que devam saber parte das semelhantes coisas" (L 1, tit. XLIV, 26).

Se estas inquirições sobre o juiz e outros funcionários não fossem realizadas. a pena seria o degredo por dois anos e multa. devendo ainda tomar as providencias que the fossem cabiveis para fazer as devidas correções ou informar a quem fosse competente para tanto ( $\mathrm{L}$ 1, tít. XLIV, 30). A mesma sanção seria aplicada caso as inquirições não fossem encaminhadas aos corregedores das comarcas, no prazo de um mês após o seu término (L 1, tít. XLIV. 31).

Nos casos dos crimes que as Ordenações determinassem as devassas, como mortes e roubos. os juizes deveriam fazer a inquirição pessoalmente. não delegando a atribuição a qualquer outra pessoa, ou seja, "devem tirar per si as inquirições, não as cometendo a outro nenhum" (L 1. tít. XLIV, 34).

Os juizes não deveriam fazer remessas dos feitos a outros superiores ou ao rei. exceto nos casos em que a legislação determinasse. Deveriam apenas tomar conhecimento dos feitos e proferir a decisão final, cabendo apclação ou agravo. Havendo remessa de modo irregular, "tudo o que se processar pelo Superior a quem forem remetidos será nenhum e de nenhum vigor", ou seja, não teria validade ( $L$ 1, tít. XLIV, 37).

A prisão era feita pelo alcaide ou muirinho, devendo constar na ordem o nome da pessoa a ser presa, exceto em situações em que se devesse guardar maior sigilo, mas mesmo assim seria levado um alvará secreto, no qual o nome da pessoa seria declarado (L 1, tít. XLIV, 39).

Mais punição ainda recairia sobre o juiz se não tomasse as providências cabíveis caso algum fidalgo praticasse algum delito ou causasse dano a terceiro, podendo o próprio magistrado responder por estes danos (I. I, tít. XI.IV, 40). 
Havia também uma recomendação de número de audiências por semana conforme a quantidade de habitantes, as quais eram aumentadas na hipótese de haver réus presos (L 1, tít. XLJV, 4I).

Interessante ainda notar que os juizes ordinários, quando andassem pelos vilarejos e cidades, deveriam usar varas vermelhas, sob pena de multa. Já os juízes de fora usavam varas brancas, estando também sujeitos à mesma penalidade. Trata-se, deste modo, de um símbolo que distinguia os dois tipos de magistraturas ( $\mathrm{L}$, tit. XLIV, 55).

Neste sentido. comenta Álvares da Silva que "a vara era o símbolo pelo qual o juiz se distinguia dos demais dos homens. Mostrava sua autoridade. impedindo que alguém, por desconhecê-la, lhe opusesse obstáculo" ${ }^{43}$

Os juízes ordinários eram eleitos, em procedimento determinado pelas Ordenações, ¿ que era organizado pelo juiz que estivesse terminando sua jurisdição. salvo se o corregedor estivesse presente, caso em que o comando da eleição e da apuração passaria para ele (L I, tit. XLV, 1).

\subsubsection{Dos Juizes de vintena}

Importante também destacar a figura do juiz de vintena. De fato, a existência deste juiz se justificava pelas reclamações das pessoas que moravam em aldeias mais distantes e que perdiam muito tempo para levar pequenas contendas ao juiz ordinário. Assim, nas aldeias em que houvesse vinte vizinhos até cinqüenta, o juiz ordinário escolheria, a cada ano, um "homem bom da dita aldeia". para que atuasse como juiz junto àquela população.

O juiz de vintena deveria resolver verbalmente as demandas, sem processo escrito, até determinada quantia, não cabendo apelação nem agravo. A sentença era logo executada. Decidia ainda sobre questões relacionadas a danos e podia efetuar prisões, encaminhando o preso para o juiz ordinário da jurisdição (L I, tít. XLIV, 64).

Nos casos de aldeias maiores, de cinqüenta até cem vizinhos, de cem até cento e cinqüenta e de duzentos para cima, os referidos juizes mantinham os mesmos poderes, podendo conhecer de causas com valores mais elevados (L I. tít. XLIV. 65-67).

43 Segundo o mesmo autor. a palavra "vara", atualmente usada no sentido de unidade judiciária, teria se originado deste instrumento utilizado pelos juizes, o que se deu através de um processo de metonímia. Assim, "como a palavra era usada para distinguir dois tipos de juiz, passou a ser empregada fora de seu contexto semânticu. para designar os diferentes setores em que se dividiu a magistratura nos tempos posteriores: varu civcl, penal, criminal, de familia, de órfâos, trabalhista, federal" (SILVA, Antônio Álvares da. Etimologia e conceito histónco da palavra "vara". Revista da Faculdade de Direito da Universidade Federal de Minas (iercis, n. 44. p. 36-38, jan./jun. 2004). 
Note-se ainda que estes juízes das pequenas aldeias não poderiam conhecer de demandas envolvendo bens de raiz, assim como também não julgavam os crimes, apenas prendiam os malfeitores e os encaminhavam ao juiz ordinário ( $\mathrm{L}$ 1, tít. XLIV, 68).

É interessante, portanto, a existência destes juizes, pois demonstra a preocupação em aproximar a justiça da sociedade, diminuindo os ônus para os mais necessitados. No mais, a atuação deles implicava uma maior celeridade na prestação jurisdicional.

\subsection{Outros cargos}

Além dos órgãos acima mencionados, muitos outros cargos existiam no aparelho de distribuição da justiça, dentre os quais podemos citar: procuradores, escrivães da Chancelaria, meirinho-mor, meirinhos-das-cadeias, escrivães-dos-feitos do Rei, almotacés, porteiros, pregoeiros, carcereiros, tabeliães e alcaides, todos com disciplina no Livro I das Ordenações.

\section{Conclusão}

Diante do exposto, vê-se que a organização judiciária portuguesa revela alguns aspectos bastante interessantes.

Inicialmente, cabe destacar a preocupação com o aproveitamento do tempo. com o controle da quantidade de trabalho dos desembargadores e outros oficiais, o que demonstra que, mesmo de forma rudimentar, havia anseios de rapidez na distribuição da justiça.

Neste mesmo sentido também as determinações relacionadas aos réus presos. enfatizando a busca por uma fiscalização da quantidade de encarcerados, os motivos da prisão e o despacho rápido dos processos das pessoas que se encontrassem nesta condição.

Destaca-se, ainda, particularmente, o sistema de controle da atuação dos magistrados e outros funcionários, que era bastante rígido. Note-se que os próprios funcionários serviam de fiscais uns dos outros, na medida em que o juiz ou corregedor que assumia logo iniciava uma investigação sobre o comportamento do antecessor.

Tal aspecto revela a necessidade de centralização do poder por parte do monarca, bem como de exercer o controle das pessoas que atuavam em seu nome na aplicação da justiça, o que talvez se justifique pela própria dificuldade de comunicação e de saber o que acontecia nos longínqüos territórios do reino. 
Igualmente notáveis eram as punições estabelecidas para estes funcionários, as quais são muito presentes ao longo de todo o texto das Ordenações Manuelinas, incluindo até pena de degredo para juízes.

Portanto. a organização judiciária portuguesa em seus primeiros tempos de formação do Estado até as Ordenações Manuelinas é uma história de erros e acertos. como tudu que é construído pelo ser humano. No entanto, demonstra a admirável persistência de um povo em criar suas instituições. buscar sua identidade e construir o próprio destino.

São Paulo, setembro de 2006.

Referências

ALMEIDA JÚNIOR, João Mendes de. U processo criminal brasileiro. 4. ed. Rio de Janeiro: Freitas Bastos. 1959. v. 1.

SILVA, Antônio Álvares da. Ftimologia e conceito histórico da palavra "vara" Rcvista da Faculdade de Direito da Universidade Federal de Minas Gerais, Belo Horizonle, n. 44, p. 27-40, jan./jun. 2004.

AZEVEDO, Luiz Carlos de. Introdução à história do direito. São Paulo: Revista dos Tribunais. 2005 .

. O reinado de D. Manuel e as Ordenações Manuelinas. Revista du Faculdade de Direito de São Paulo, São Paulo, v. 95, p. 19-32, 2000.

BARRUS, Henrique da Liama. História da administração pública em Portugal nos séculos XII e $X V$. 2. ed. Lisboa: Livraria Sá da Costa, 1946. t. 3.

CAETANO, Marcello. História do direito português - sécs. XII XV. 4. ed. Lisboa: Verbo, 2000. CÂMARA, José. Subsidios para a história do direito pátrio. Rio de Janeiro: Serviço Gráficu do Instituto Brasileiro de Geografia e Estatística, 1954. 1. I.

DFLGADO, Luiz. Quadro histórico do direito hrasileiro. Recife: Editora da Universidade Fedural de Pernambuco, 1974.

GRANDE Enciclopédia Porluguesa e Brasileira. Lisboa; Rio de Janeiro: Editorial Enciclopédia, 1935-60, v. VI, VII, VIII, XIV, XIX, XXIV, XXX, XXXII. 
HE:SPANHA, Manuel António. História das Instituições: época medieval e moderna. Coimbra: Almedina, 1982.

ORDENAÇÕES Manuelinas. Lisboa: Calouste Gulbenkian, 1984. v. I e III.

PERFS, Damião. História de Porlugal: edição monumental comemorativa do $8^{\circ}$ centenário da fundação da nacionalidade. Porto: Editora Portucalense, 1929. v. II.

ROCHA, M. A. Coelho da. Ensaio sobre a história do governo e legislação de Portugal. 7. ed. Coimbra: Imprensa da Universidade, 1896.

SILVA, Agathe E. Schmidt da. As ordenaçōes Filipinas e o direito brasileiro. Revista Fstudos Juridicos, São Leopoldo. Universidade do Vale do Rio dos Sinos, v. 28, n. 73, p. 59-84, maio/ago. 1995.

SILVA, Nuno J. Gomes da. Spinosa. História do direito português: fontes de direito. 3. ed. Lisboa: Calouste Gulbenkian, 2000.

VElASCO, Ignácio M. Poveda. Ordenações do reino de Portugal. Revista da Faculdade de Direito da Universidade de São Paulo, São Paulo, v. 89, p. 11-67, jan.idez. 1994. 